Original Research Paper

\title{
Andaliman (Zanthoxylum Acanthopodium DC.), a Rare Endemic Plant from North Sumatra that Rich in Essential Oils and Potentially as Antioxidant and Antibacterial
}

\author{
Nommensen Pangihutan Ompusunggu \& Wahyu Irawati* \\ Pogram Studi Pendidikan Biologi, Universitas Pelita Harapan, Tangerang, Indonesia
}

\author{
Article History \\ Received : September $16^{\text {th }}, 2021$ \\ Revised : October $30^{\text {th }}, 2021$ \\ Accepted : November $03^{\text {th }}, 2021$ \\ Published : November $13^{\text {th }}, 2021$
}

*Corresponding Author:

Wahyu Irawati,

Universitas Pelita Harapan,

Tangerang, Indonesia

Email:w.irawati3@gmail.com

\begin{abstract}
Andaliman (Zanthoxylum acanthopodium DC.) is one of the endemic plants originating from North Sumatra. This plant is known for its benefits as a special seasoning spice in Batak tribe community. Humans as the image of God are given the ability to conduct an investigation and development of what God has created so that science begins to develop to investigate the potential of andaliman plants in the field of health. This writing aims to determine: 1) morphological and physiological characteristics of andaliman, 2) habitat of andaliman, and 3) utilization of andaliman as antioxidant and antibacterial agent. The method of writing used in the preparation of this article is the study of literature. The results of the literature study show that the andaliman plant has a tap root, woody stems, green, odd-numbered and jagged-edged compound leaves, pale yellow flowers, pepper-shaped fruits, and shiny black or wrinkled black seeds with thick and hard seed shells. Andaliman habitat is a place with an altitude of 1200-1500 masl with an average temperature of $15-18^{\circ} \mathrm{C}$ and rainfall of 800$1000 \mathrm{~mm} /$ year and soil $\mathrm{pH}$ 5.5-7.6. Andaliman fruit contains 29 components of essential oils such as geranyl, cytronella, $\beta$-cytronelol, and nerol which have antioxidant activity. Andaliman fruit extract also has antibacterial activity, which inhibits the growth of microbes such as Escherichia coli, Salmonella typhimurium, Bacillus cereus, Pseudomonas fluorescens, Aspergillus flavus, Propionibacterium acnes and Staphylococcus aureus.
\end{abstract}

Keywords: Andaliman; Antibacterial; Antioxidant.

\section{Pendahuluan}

Indonesia

sebagai

megabiodiversitas memiliki spesies flora mencapai 20.000 spesies. $40 \%$ dari total jumlah spesies tersebut merupakan tumbuhan yang hanya terdapat di wilayah-wilayah tertentu di Indonesia dan sebagai tumbuhan endemik (Kusuma \& Hikmat, 2015). Selain itu, tumbuhan endemik adalah jenis tumbuhan langka.

Tumbuhan endemik langka yang ada di sssssIndonesia adalah andaliman (Zanthoxylum acanthopodium DC.) yang tumbuh di wilayah sekitar Danau Toba, Sumatera Utara (Panggabean et al., 2020). Selanjutnya, Andaliman dikenal secara luas dan dimanfaatkan oleh orang-orang suku Batak, dan memiliki beberapa nama, khususnya pada komkunitas
Batak (Simbolon Isma et al., 2018). Masyarakat Batak Karo menyebutnya itir-itir, masyarakat Batak Simalungun dan Pakpak menyebutnya tuba, sedangkan masyarakat Batak Angkola menyebutnya sinyar-sinyar atau sinyarnyar (Raja \& Hartana, 2017). Masyarakat suku Batak telah mengelola dan memanfaatkan buah andaliman untuk berbagai tujuan selain sebagai sumber makanan. Secara tradisional, masyarakat Batak juga menggunakan buah andaliman untuk mengatasi masalah pencernaan, mengurangi rasa sakit, dan meredakan diare (Yanti et al., 2011).

Buah andaliman merupakan "sumber makanan" khas suku Batak dan biasanya dimanfaatkan sebagai bumbu masak dengan nama "merica Batak" (Emil \& Sri, 2020). Andaliman (Zanthoxylum acanthopodium DC.) merupakan salah satu anggota famili Rutaceae 
yang hidup secara liar di Provinsi Sumatera Utara. Tumbuhan semak ini dapat tumbuh setinggi 5 meter. Batangnya berkayu dan bercabang yang keduanya berduri. Daun tanaman ini adalah daun majemuk menyirip ganjil yang ditandai dengan adanya satu anak daun di ujung tulang daun utama. Buahnya berbentuk bulat dengan aroma yang khas (Miftakhurohmah \& Suhirman, 2009).

Hasil penelitian menunjukkan bahwa andaliman juga bermanfaat sebagai tanaman obat khususnya sebagai agen antioksidasi (Kristanty \& Suriawati, 2015) dan antibakteri (Miftakhurohmah \& Suhirman, 2009). Penelitian andaliman di bidang kesehatan mulai banyak dilakukan terutama untuk menguak manfaat minyak atsiri yang terkandung di dalam buah andaliman serta manfaatnya sebagai antibakteri dan antioksidan (Kristanty \& Suriawati, 2014).

Kristanty dan Suriawati (2015) menunjukkan bahwa semua bagian tubuh tumbuhan andaliman memiliki manfaat bagi manusia. Namun demikian belum ada penelitian yang komprehensip sebagai informasi ilmiah tentang tumbuhan andaliman. Oleh karena itu perlu dilakukan penelitian tentang tumbuhan andaliman dari aspek morfologi, fisiologi, habitat, dan pemanfaatan andaliman untuk mengkaji: 1) karakteristik morfologi dan fisiologi andaliman, 2) habitatnya di alam, serta 3) pemanfaatan andaliman sebagai antioksidan dan antibakteri.

\section{Bahan dan Metode}

Metode penelitian yang digunakan adalah studi literatur. Studi literatur adalah upaya untuk menjawab rumusan masalah dengan mengkaji beberapa literatur/referensi yang berhubungan dengan masalah tersebut (Hasan \& Ritonga, 2018). Hal-hal yang perlu diperhatikan dalam studi literatur adalah mengumpulkan data, membaca dan mengolah bahan pustaka untuk dijadikan sebagai acuan dalam membahas permasalahan (Khatibah, 2011). Informasi dikumpulkan berupa data hasil penelitian dari berbagai sumber untuk menjawab rumusan masalah serta tujuan penulisan artikel. Informasi diperoleh melalui Google Scholar dengan kata kunci karakteristik morfologi dan fisiologi andaliman, habitat andaliman, dan pemanfaatan andaliman sebagai antioksidan dan antibakteri. Jumlah jurnal yang relevan dalam penulisan artikel ilmiah ini adalah 30 .

\section{Hasil dan Pembahasan}

Hasil penelitian memuat pembahasan yang relevan dengan tujuan artikel ilmiah. Pembahasan diperoleh dari kajian literatur yang penulis lakukan secara bertahap dan berkelanjutan untuk mendapatkan data yang sesuai dan benar-benar relevan. Data - data yang diperoleh kemudian dianalisa.

\section{Karakteristik Morfologis dan Fisiologis}

Klasifikasi tanaman andaliman menurut Medhi, Deka, dan Bhau (2013) dapat dilihat pada Tabel 1.

Tabel 1. Klasifikasi tanaman andaliman (Medhi et al., 2013)

\begin{tabular}{cc}
\hline Kingdom & Plantae \\
Filum & Tracheophyta \\
Kelas & Magnoliopsida \\
Ordo & Rutales \\
Famili & Rutaceae \\
Genus & Zanthoxylum \\
Spesies & Zanthoxylum acanthopodium \\
& DC. \\
\hline
\end{tabular}

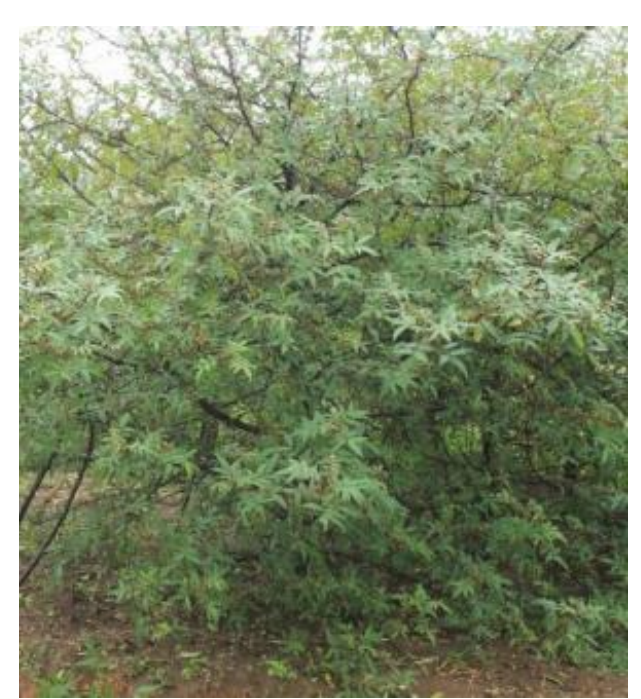

Gambar 1. Tanaman Andaliman (Raja \& Hartana, 2017). 

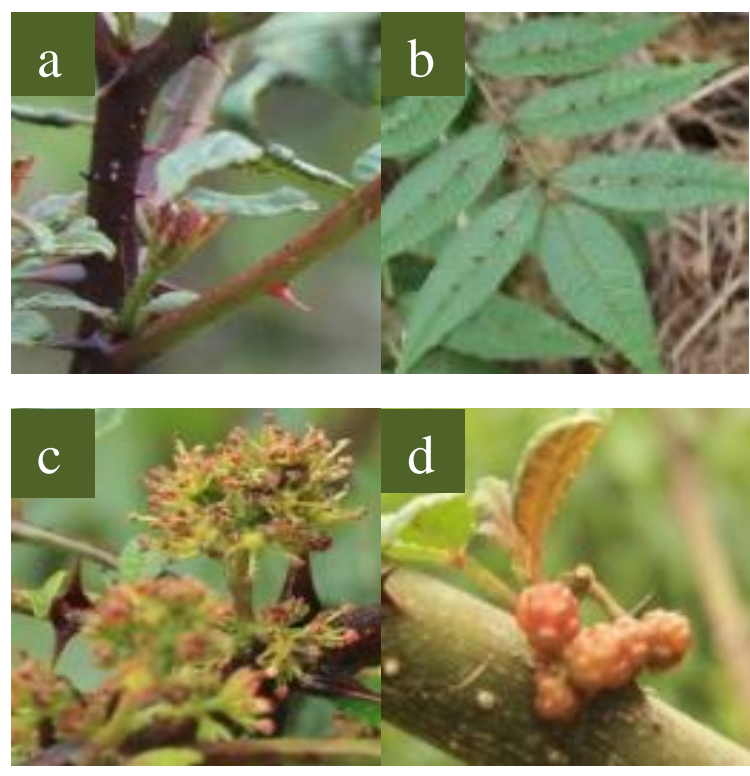

Gambar 2. Bagian-bagian tubuh tumbuhan andaliman: a) Batang andaliman, b) Daun andaliman, c) Bunga andaliman, d) Buah andaliman (Raja \& Hartana, 2017).

Morfologi tanaman andaliman dapat dilihat pada Gambar 1 dan 2. Batang tanaman andaliman berkayu dan berduri, batang berkisar antara 3-8 $\mathrm{m}$, batang dan ditutupi rambut berwarna merah kehitaman atau hijau tua kecoklatan (Batubara et al., 2017). Beberapa verietas memiliki duri di batangnya, dan beberapa yang lain tidak memiliki duri. Pada batang yang terdapat duri, biasanya duri berbentuk segitiga runcing atau seperti kait. Batang andaliman juga memiliki cabang. Percabangannya muncul pada batang utama ataupun jauh dari batang utamanya (Raja \& Hartana, 2017).

Permukaan kulit batang andaliman berwarna abu-abu kehijauan atau cokelat muda keabuan (Gambar 2a). Kulit akar dan daun tumbuhan ini digunakan untuk mengatasi sakit perut, sakit gigi, batuk, penyakit pada kelamin, diare, dan encok oleh masyarakat Batak secara tradisional (Kristanty \& Suriawati, 2015). Bagian akar dan kulit tumbuhan ini menghasilkan dua senyawa alkaloid aktif, yaitu canthin-6-one dan pellitorine yang manfaatnya secara berturut-turut adalah sebagai fungisida dan insektisida ( $\mathrm{He}$ et al., 2002).

Daun andaliman berwarna hijau dengan gerigi di tepinya (Gambar 2b). Daunnya adalah daun majemuk berjumlah ganjil yang ditandai dengan adanya anak daun di ujung tulang daun utama (Raja \& Hartana, 2017). Daun majemuk menyirip gasal atau disebut juga daun anak tiga, panjang daun berkisar antara 2-25 $\mathrm{cm}$ dengan anak daun 3-7, ditumbuhi oleh duri, berbentuk bundar telur hingga jorong-lanset, berukuran $1-12 \times 0,5-4,5 \mathrm{~cm}$, pangkal tumpul, tepi rata atau mengerut berkelenjar, ujung runcing atau meruncing (Silalahi et al., 2021). Daunnya mengandung minyak atsiri. Minyak atsiri dari daun andaliman mampu menghambat pertumbuhan jamur Colletortichum gloesporoides dan Botryodiplodia theobromae yang merupakan patogen bagi tumbuhan (R. K. Dubey, Kumar, Jaya, \& N. K. Dubey, 2009).

Bunga tumbuhan andaliman tumbuh di ketiak daun ataupun pada batangnya (Gambar 2c). Bunganya berkelamin dua dan memiliki warna kuning pucat. Bunga andaliman termasuk pada bunga majemuk terbatas, anak payung menggarpu majemuk, kecil-kecil; dasar bunga rata atau bentuk kerucut (Batubara et al., 2020). Warna kelopak bunganya adalah hijau kekuningan atau hijau kemerahan (Raja \& Hartana, 2017). Panjang bunganya adalah sekitar 1-2 sentimeter. Jumlah kelopak bunganya sekitar 5-7 buah dengan 5-6 benang sari berwarna merah atau ungu kemerahan dan jumlah putik 3-4 buah. Akibatnya, satu bunga dapat menghasilkan sampai dengan empat buah andaliman (Siregar, 2012; Raja \& Hartana, 2017).

Buah tanaman ini berbentuk seperti lada berwarna hijau ketika masih mentah, kemerahan ketika sudah matang (Raja \& Hartana, 2017), dan menghitam ketika dikeringkan. Setiap buah hanya memiliki satu biji. Buah andaliman segar dapat dilihat pada Gambar 2d. Buah adalah bagian yang paling banyak dimanfaatkan dari tumbuhan ini. Selain untuk memberi citarasa pada makanan, buah dari tumbuhan ini sering diambil ekstraknya untuk dieksplorasi manfaat zat yang terkandung di dalamnya oleh para peneliti lainnya. Negi, Bish, Bhandari, Singh, dan Sundriyah (2011) mengungkap beberapa aktivitas biologis yang terdapat di dalam ekstrak andaliman, seperti larvasida, antiinflamasi, analgesik, antioksidan, antibiotik, senyawa hepatoprotektif, antiplasmodial, sitotoksik, antiproliferasi, anticacing, antivirus, antijamur, dan antikonvulsan.

Biji andaliman berwarna hitam kilat dan memiliki kulit dengan struktur yang sangat keras. 
Beberapa varietas dilaporkan memiliki biji yang keriput (Raja \& Hartana, 2017). Struktur yang keras ini mampu menghambat imbibisi air dan pertukaran gas untuk perkecambahannya. Oleh sebab itu, daya perkecambahan dan regenerasi tumbuhan andaliman tergolong sangat rendah. Berbeda dengan rempah lainnya, andaliman tidak ditanam, melainkan disebarkan oleh burung setelah memakan buah andaliman tersebut yang dibuktikan dengan tidak ditemukannya anakan andaliman di sekitar pohon dewasanya (Asbur \& Khairunnisyah, 2018). Sistem akar pada andaliman adalah akar tunggang, yaitu akar lembaga akan terus tumbuh menjadi akar pokok yang bercabang-cabang akhirnya menjadi akarakar yang lebih kecil dan berbulu halus di seluruh permukaannya (Anggraeni, 2020).

\section{Habitat}

Di Indonesia, persebaran tumbuhan andaliman adalah di sekitar Danau Toba, yang meliputi Kabupaten Karo, Kabupaten Simalungun, Kabupaten Toba Samosir, Kabupaten Samosir, Kabupaten Humbang Hasundutan, Kabupaten Tapanuli Utara, dan Kabupaten Dairi (Harsono, Kurniawan, Prakasa, Syahfitri, Husna, \& Prasetya, 2016. Andaliman tumbuh secara optimal di daerah khatulistiwa pada ketinggian 1200-1500 meter di atas permukaan laut. Temperatur optimum pertumbuhannya berkisar antara $15-18^{\circ} \mathrm{C}$ (Sinaga \& Prasetyo, 2019). Curah hujan habitat andaliman adalah sekitar $800-1000 \mathrm{~mm} /$ tahun dengan kelembaban yang tinggi. Tanaman ini tumbuh pada $\mathrm{pH}$ sekitar 5,5-7,6 (Sebayang, 2015).

Jumlah populasi andaliman saat ini berkisar antara 1000-2000 pohon. Populasi andaliman mulai mengalami ancaman dari aktivitas manusia. Kegiatan seperti penebangan hutan sembarangan dan perubahan fungsi hutan menjadi perkebunan mengakibatkan habitat dan populasi andaliman mengalami ancaman serius (Harsono et al., 2016). Sampai saat ini, belum ada usaha yang cukup baik untuk dapat membudidayakan tumbuhan ini karena struktur bijinya menghambat imbibisi air dalam proses perkecambahan dan di dalam bijinya terdapat senyawa aromatik yang menghambat perkecambahan dengan kuat (Siregar, 2012). \begin{tabular}{llr}
\multicolumn{1}{c}{ Kegiatan } & \multicolumn{1}{c}{ manusia dengan cara } \\
mengeksploitasi & tanaman andaliman tanpa \\
memerhatikan & kelestariannya merupakan
\end{tabular} gambaran kejatuhan manusia dalam dosa. Manusia seringkali secara sadar maupun tidak sadar merusak hutan sehingga secara tidak langsung mengakibatkan kerusakan habitat tanaman tersebut. Tindakan yang tidak bertanggungjawab tersebut mengakibatkan pengurangan populasi andaliman secara drastis sehingga membuat andaliman menjadi tanaman langka. Manusia sebagai mahkota ciptaan-Nya bertanggungjawab melaksanakan mandat ilahi dengan cara menjaga kelestarian andaliman sebagai tanaman endemik Indonesia. Manusia diberi akal dan pikiran oleh Allah untuk memikirkan bagaimana cara perkembangbiakan tanaman andaliman sehingga tanaman ini tetap terus menjadi aset kekayaan alam endemik Indonesia. Hal-hal yang dapat dilakukan oleh manusia adalah dengan melakukan perbanyakan tanaman secara vegetatif, baik secara konvensional seperti cangkok maupun dengan memanfaatkan kecanggihan teknologi seperti kultur jaringan serta rekayasa genetika.

\section{Pemanfaatan andaliman sebagai antioksidan dan antibakteri}

Radikal bebas berbahaya untuk kesehatan manusia karena dapat menyebabkan berbagai penyakit degeneratif seperti diabetes, kanker, aterosklerosis, dan hipertensi. Pencegahan pembentukan radikal bebas, salah satunya dengan cara meningkatkan pertahanan tubuh dengan memperbanyak antioksidan (Meutia \& Wardayanie, 2015). BHA (Butil Hidroksi Anisol) dan BHT (Butil Hidroksi Toluen) sangat efektif dalam menghambat radikal bebas, tetapi penggunaan BHA dan dan BHT menimbulkan efek samping, menyebabkan pembengkakan hati dan mempengaruhi aktivitas enzim didalam hati (Tarigan et al., 2020). Kekhawatiran akan efek samping antioksidan sintesis sehingga dicari alternatif antioksidan yang lebih aman. Salah satu bahan alam yang mengandung antioksidan adalah andaliman (Zanthoxylum acanthopodium, DC), untuk mendapatkan dapat dilakukan ekstraksi dengan metode DDPH (Heliawati et al., 2019).

Berdasarkan penelitian yang dilakukan oleh Moektiwardoya, Muchtaridi, dan Halimah 
(2014), diketahui bahwa buah andaliman mengandung minyak atsiri yang terdiri atas banyak komponen penyusunnya (Tabel 2). Tabel 2 menunjukkan bahwa terdapat 29 komponen penyusun minyak atsiri di dalam ekstrak buah andaliman. Empat komponen terbesar penyusun minyak atsiri dari ekstrak buah andaliman adalah geranil asetat $(23,18 \%)$, sitronela $(11,23 \%), \beta-$ sitronelol (10,64\%), dan nerol $(8,20 \%)$. Beberapa komponen di atas memiliki sifat antioksidan, tetapi beberapa yang lain tidak.

Hanum dan Laila (2016) mengatakan bahwa kandungan minyak atsiri di dalam buah andaliman dapat menangkal aktivitas oksidasi yang dilakukan oleh radikal bebas seperti 2,2diphenyl-1-picrylhydrazyl (DPPH). Nilai konsentrasi inhibitor minyak atsiri terhadap DPPH adalah sebesar 100,76 $\mu \mathrm{g} / \mathrm{ml}$. Mengacu pada skala yang ditetapkan oleh Mardawati, Achyar, dan Marta (2008), maka dapat dikatakan bahwa kandungan minyak atsiri pada buah andaliman dikategorikan sebagai antioksidan menengah-kuat.

Tabel 2. Komposisi kimia minyak atsiri dari buah (Moektiwardoya et.al 2014)

\begin{tabular}{|c|c|c|}
\hline No & Nama Komponen & $\begin{array}{c}\text { Konsentrasi } \\
(\%)\end{array}$ \\
\hline 1 & $\alpha$-pinene & 2,15 \\
\hline 2 & $\alpha$-phellandrene & 1,57 \\
\hline 3 & $\begin{array}{l}\text { 6-methyl-5- } \\
\text { heptene-2-one }\end{array}$ & 0,33 \\
\hline 4 & Limonene & 5,81 \\
\hline 5 & $\alpha$-terpineol & 0,82 \\
\hline 6 & linanool oxide & 0,081 \\
\hline 7 & Linanool & 5,65 \\
\hline 8 & Citronella & 11,23 \\
\hline 9 & Undecane & 1,28 \\
\hline 10 & limonene-oxide & 0,86 \\
\hline 11 & Sopulegol & 1,82 \\
\hline 12 & $\beta$-citronelol & 10,64 \\
\hline 13 & Nerol & 8,20 \\
\hline 14 & Geraniol & 4,25 \\
\hline 15 & citronellyl acetate & 2,70 \\
\hline 16 & geranyl acetate & 23,18 \\
\hline 17 & neryl acetate & 1,53 \\
\hline 18 & Caryophyllene & 3,05 \\
\hline 19 & $\beta$-fernesene & 0,68 \\
\hline 20 & $\alpha$-caryophyllene & 0,72 \\
\hline 21 & hydroxy-linalool & 0,38 \\
\hline 22 & Germacrene & 1,37 \\
\hline 23 & Aromadendrene & 1,06 \\
\hline
\end{tabular}

\begin{tabular}{lll}
\hline 24 & Nerolidol & 0,58 \\
25 & 1-Naptalenol & 0,86 \\
26 & Tetradecanal & 0,18 \\
27 & e-myrtenol & 0,14 \\
28 & Farnesol & 0,39 \\
29 & farnecyl acetate & 0,40 \\
\hline
\end{tabular}

Selain memiliki peranan sebagai antioksidan, hasil penelitian Miftakhurohmah dan Suhirman (2009) menunjukkan bahwa ekstrak buah andaliman dapat mengurangi aktivitas pertumbuhan mikroba, seperti Escherichia coli, Salmonella typhimurium, Bacillus cereus, Staphylococcus aureus, Pseudomonas fluorescens, dan Aspergillus flavus. Kemampuan ekstrak pada buah andaliman yaitu etil asetat dapat mengambat pertumbuhan bakterinya disebabkan oleh senyawa-senyawa anti bakteri yang terkandung didalamnya (Sitanggang et al., 2019). Hanum dan Laila (2016) juga melaporkan adanya aktivitas antibakteri pada Ekstrak Etanolik Andaliman (EEA). Ekstrak etanolik andaliman diujikan pada dua jenis bakteri, yaitu Propionibacterium acnes dan Staphylococcus aureus. Aktivitas antibakteri diukur dengan terbentuknya zona hambatan (clear zone) pada medium tumbuh bakteri yang telah ditambahkan EEA. Aktivitas antibakteri ekstrak buah andaliman dapat dilihat pada Tabel 3.

Tabel 3. Aktivitas antibakteri EEA (Hanum \& Laila 2016; Maria et al., 2015; Susanti \& Situmorang, 2020)

\begin{tabular}{lcccc}
\hline Jenis Bakteri & $\begin{array}{c}\text { Konsentrasi } \\
\text { EEA } \\
(\mathbf{m g} / \mathbf{m l})\end{array}$ & $\begin{array}{c}\text { Diameter Zona } \\
\text { Hambatan }\end{array}$ \\
& 300 & 15,95 & \pm & 0,46 \\
& 200 & 14,63 & \pm & 0,52 \\
Propionibacterium & 100 & 13,04 & \pm & 0,42 \\
acnes & 60 & 10,22 & \pm & 0,35 \\
& 30 & 6,56 & \pm & 0,55 \\
\hline & 300 & 14,61 & \pm & 0,53 \\
& 200 & 13,14 & \pm & 0,68 \\
Staphylococcus & 100 & 12,85 & \pm & 0,41 \\
aureus & 60 & 9,80 & \pm & 0,66 \\
& 30 & 6,26 & \pm & 0,68 \\
\hline
\end{tabular}




\begin{tabular}{lcccc}
\hline & 10 & 0,65 & \pm & 0,91 \\
& 20 & 3,15 & \pm & 0,21 \\
& 30 & 5,25 & \pm & 0,49 \\
& 40 & 6,35 & \pm & 0,63 \\
Escherichia coli & 50 & 6,60 & \pm & 0,70 \\
& 60 & 7,20 & \pm & 0,70 \\
& 70 & 7,65 & \pm & 0,63 \\
& 80 & 8,15 & \pm & 0,35 \\
& 90 & 8,30 & \pm & 0,42 \\
& 100 & 9,60 & \pm & 0,56 \\
Salmonella & & & & \\
\hline & 12,5 & 7,9 & \pm & 12,3 \\
& 25 & 11,2 & \pm & 12,2 \\
& 50 & 15,4 & \pm & 13,9 \\
& 75 & 8,0 & \pm & 15,1 \\
& & & & \\
\hline & 12,5 & 10,2 & \pm & 7,2 \\
Bacillus subtilis & 25 & 6,6 & \pm & 8,5 \\
& 50 & 6,8 & \pm & 11,7 \\
& 75 & 8,4 & \pm & 12,4 \\
\hline
\end{tabular}

Tabel 3 menunjukkan bahwa EEA mampu menghambat pertumbuhan kedua jenis bakteri tersebut dengan baik pada konsentrasi 100 $\mathrm{mg} / \mathrm{ml}$. Selain itu, dapat juga disimpulkan bahwa zona hambatan akan semakin luas apabila konsentrasi EEA ditambahkan. Dengan demikian, EEA memiliki aktivitas antibakteri yang menguntungkan bagi manusia.

\section{Kesimpulan}

Ciri morfologis dan fisiologis tanaman andaliman adalah akarnya tunggang, batangnya berkayu dengan kulit berwarna abu-abu kehijauan, daunnya majemuk ganjil berwarna hijau bergerigi, bunganya berwarna kuning pucat dengan kelopak berwarna hijau kekuningan, buahnya berbentuk seperti lada dengan warna hijau dan hitam ketika dikeringkan, bijinya berwarna hitam mengkilat dengan kulit biji yang tebal dan keras. Habitat andaliman adalah tempat dengan ketinggian 1200-1500 mdpl dengan suhu rata-rata $15-18^{\circ} \mathrm{C}$ dan curah hujan 800-1000 $\mathrm{mm} /$ tahun serta $\mathrm{pH}$ tanah 5,5-7,6. Buah andaliman mengandung banyak minyak atsiri yang bermanfaat sebagai antioksidan dan antibakteri. Ekstrak buah andaliman juga memiliki aktivitas antibakteri, yaitu menghambat pertumbuhan mikroba seperti Escherichia coli, Salmonella typhimurium, Bacillus cereus, Pseudomonas fluorescens, Aspergillus flavus,
Propionibacterium acnes dan Staphylococcus aureus.

\section{Ucapan terima kasih}

Terima kasih kepada Kristin Pasaribu dan DamaiYanti Manalu yang ikut membantu selama proses penulisan.

\section{Referensi}

Asbur, Y., Khairunnisyah. (2018). Pemanfaatan andaliman (Zanthoxylum acanthopodium DC) sebagai tanaman penghasil minyak atsiri, Jurnal Kultivasi, 17(1), 537-543. https://www.researchgate.net/publication/ 327230510_Pemanfatan_andaliman_Zant hoxylum_acanthopodium_DC_sebagai_ta naman_penghasil_minyak_atsiri

Anggraeni, R. (2020). Uji Karakteristik Simplisia Buah Andaliman (Zanthoxylum acanthopodium DC .). 3(2), 32-38.

https://www.scribd.com/document/32701

6278/Wihp-32-01-Kompilasi-1912

Batubara, M. S., Sabri, E., \& Tanjung, M. (2017). Pengaruh pemberian ekstrak etanol daun andaliman (Zanthoxylum acanthopodium DC ) Terhadap Gambaran Morfologi Ovarium Mencit (Mus musculus L.). Klorofil, 1(1), 5-10. http://dx.doi.org/10.30821/kfl:jibt.v1i1.12 $\underline{32}$

Batubara, M. S., Sabri, E., \& Tanjung, M. (2020). Pengaruh Pemberian Ekstrak Daun Andaliman (Zanthoxylum acanthopodium DC.) Terhadap Histologis Ovarium Mencit (Mus musculus L.). BIOLINK (Jurnal Biologi Lingkungan Industri Kesehatan), 6(2),196-209. https://doi.org/10.31289/biolink.v6i2.240 $\underline{9}$

Dubey, R. K., Kumar, R., Jaya, \& Dubey, N. K. (2009). Evaluation of Eupatorium cannabium Linn. oil in enhancement of shelf life of mango fruits from fungal rotting, World Journal of Microbiology and Biotechnology, 8(23), 467-473. 
https://doi.org/10.1007/s11274-006-9248$\underline{8}$

Emil, M., \& Sri, P. (2020). ( Zanthoxylum Acanthopodium DC . ) Dengan Pengering Swirl Fluidized Bed ( The drying characteristic of andaliman ( Zanthoxylum Acanthopodium DC . ) by swirl fluidized bed dryer ). Jurnal Teknologi Pangan Dan Gizi, 19(1), 14-21. https://core.ac.uk/download/pdf/32594743 $\underline{5 . p d f}$

Hanum, I. T. \& Laila, L. (2016). Physical evaluation of anti-aging and anti-acne andaliman Zanthoxylum acanthopodium $D C$.) ethanolic extract peel off gel mask. Der Pharma Chemica, 8(23), 6-10. https://www.researchgate.net/publication/ 316886976_Physical_evaluation_of_antiaging and anti-

acne andaliman zanthoxylum acanthopo dium dc ethanolic extract peel off gel $\underline{\text { mask }}$

Harsono, T., Kurniawan, A. S., Prakasa, H., Syahfitri, D., Husna, F., \& Prasetya, E. (2016). Analisis spasial geofrafi dan maximum entropy untuk menentukan zona konservasi in situ pada andaliman (Zanthoxylum acanthopodium DC.) di Sumatera Utara. Prosiding Seminar Nasional Perhimpunan Pemuliaan Indonesia (PERIPI) Komda Riau. 224232.

http://digilib.unimed.ac.id/id/eprint/35296

Hasan, I., \& Ritonga, A. (2018). Konsep pembaharuan pembelajaran ekonomi pada abad XXI. Prosiding Seminar Nasional "Membangun Generasi Emas 2045 yang Berkarakter dan Melek IT" dan Pelatihan "Berpikir Suprarasional”. 426-434.

He, W., Van Puyvelde, L., De Kimpe, N., Verbruggen, L., Anthonissen, K., Van der Flaas, M., ... Mudida, F. P. (2002). Chemical constituents and biological activities of Zanthoxylum usambarense. Phytotherapy Research, 16, 66-70. https://doi.org/10.1002/ptr.849
Heliawati, L., Rienoviara, \& Khoiriyah, A. (2019). Aktivitas Antioksidan dan Identifikasi Senyawa Aktif dalam Ekstrak Buah Andaliman (Zanthoxylum acanthopodium DC .). 36(2), 124-130. https://www.bing.com/search?q=Heliawat $\mathrm{i} \% 2 \mathrm{C}+\mathrm{L} . \% 2 \mathrm{C}+\mathrm{Rienoviara} \% 2 \mathrm{C}+\% 26+\mathrm{Kh}$ oiriyah\%2C+A.+\%282019\%29.+Aktivita s+Antioksidan+dan+Identifikasi+Senyaw a+Aktif+dalam+Ekstrak+Buah+Andalima n+\%28Zanthoxylum+acanthopodium+DC

Khatibah (2011). Penelitian kepustakaan. Jurnal Iqra', 5(1). 36-39. https://www.bing.com/search?q=Khatibah .$+\% 282011 \% 29 .+$ Penelitian+kepustakaan. + Jurnal+Iqra\%E2\% 80\% 99\&qs=n\&form= QBRE\&msbsrank $=0 \_0 \_0 \& s p=-$ $1 \& p q=$ khatibah.+\%282011\%29.+penelitia n+kepustakaan.

Kristanty, R. E. \& Suriawati, J. (2014). Cytotoxic and antioxidant activity of petroleum extract of andaliman fruits (Zanthoxylum acanthopodium DC.). International Journal of Pharmtech Research, 6(3), 1064-1069.

https://sphinxsai.com/2014/phvolpt3/3/(10 64-1069)Jul-Aug14.pdf

Kristanty, R. E. \& Suriawati, J. (2015). The Indonesian Zanthoxylum acanthopodium DC.: Chemical and biological values, International Journal of Pharmtech Research, 8(6), 313-321. https://www.sphinxsai.com/2015/ph_vol8 no6/2/(313-321)V8N6PT.pdf

Kusmana, C. \& Hikmat, A. (2015). Keanekaragaman hayati flora di Indonesia. Jurnal Pengelolaan Sumberdaya Alam dan Lingkungan, 5(2), 187-198. doi: 10.19081/jpsl.5.2.187.

Silalahi, M., Lumbantobing, K., Studi, P., Biologi, P., Indonesia, U. K., Program, M., Pendidikan, S., \& Indonesia, U. K. (2021). Kandungan Minyak Atsiri Andaliman (Zanthoxylum acanthopodium DC) dan Bioaktivitasnya. Jurnal Pro-Life, 8(1), 2231. 
https://www.researchgate.net/publication/ 350545592_Andaliman

Simbolon Isma, W., Kardhinata, E. H., Bangun, M. K., \& Simatupang, S. (2018). Identifikasi Karakter Morfologis Andaliman (Zanthoxylum acanthopodium DC.) di Beberapa Kabupaten di Sumatera Utara. 6(4), 745-756. https://www.bing.com/search?q=Simbol+ Identifikasi+Karakter+Morfologis+Andali man+\%28Zanthoxylum+acanthopodium+ DC.\%29+di+Beberapa+Kabupaten

Sinaga, R. E., \& Prasetyo, H. A. (2019). Upaya Memperpanjang Masa Simpan Andaliman ( Zanthoxylum acanthopodium D) Studi Kasus Desa Bandar Huta Usang Kabupaten Dairi Universitas Quality Email: $\quad$ roidasinaga20@gmail.com Abstrak. Agroteknosains, 3(02), 1-7. portaluniversitasquality.ac.id:5388/ojssyst em/... PDF file

Sitanggang, F. M. C., Duniaji, A. S., \& Pratiwi, I. D. P. K. (2019). Daya Hambat Ekstrak Buah Andaliman (Zanthoxylum acanthopodium DC) Dalam Etil Asetat Terhadap Pertumbuhan Escherichia coli. Jurnal Ilmu Dan Teknologi Pangan (ITEPA), $\quad 8(3), \quad 257$. https://doi.org/10.24843/itepa.2019.v08.i0 3.p04

Maria, F., Slamet, A., \& Putu, I. D. (2019). DAYA HAMBAT EKSTRAK BUAH ANDALIMAN (Zanthoxylum acanthopodium DC) DALAM ETIL ASETAT TERHADAP PERTUMBUHAN Escherichia coli. Jurnal Ilmu dan Teknologi Pangan, 257266.

Medhi, K., Deka, M., \& Bhau, B. S. (2013). The genus Zanthoxylum - A stockpile of biological and ethnomedicinal properties. Open Access Scientific Reports. doi: $10.4172 /$ scientificreports. 697

Meutia, Y. R., \& Wardayanie, N. I. A. (2015). Pengaruh Pengeringan Terhadap Komponen Volatil Yang Terlibat Pada
Ekstraksi Andaliman (Zanthoxylum acanthopodium DC) (Effect of Dehydration of Fruit on Volatile Aroma Constituents of Andaliman Zanthoxylum acanthopodium DC). Jurnal Hasil Penelitian Industri, 28(2), 104-113. https://www.researchgate.net/publication/ 291349341_Sifat_Fungsional_Tepung_K oro_Kratok_Hitam_Merah_dan_Putih_Ph aseolus_lunatus_L_dengan_Perlakuan_La ma_Perendaman

Miftakhurohmah and Suhirman, S. (2009). Potensi andaliman sebagai antioksidan dan antimikroba alami. Warta Penelitian dan Pengembangan Tanaman Industri, 15(2), 8-10. http://dx.doi.org/10.23960/aec.v5.i2.2020. p155-168 Anal.Environ.Chem.

Moektiwardoyo, M., Muchtaridi, M., \& Halimah, E. (2014). Chemical composition and locomotor activity of andaliman fruits (Zanthoxylum acanthopodium DC.) essential oil on mice. International Journal of Pharmacy and Pharmaceutical Sciences, 6 (2), 547-550. https://www.researchgate.net/journal/Inte rnational-Journal-of-Pharmacy-andPharmaceutical-Sciences-0975-1491

Negi, J. S., Bish, V. K., Bhandari, A. K., Singh, P., \& Sundriyah, R. C. (2011). Chemical constituents and biological activities of the genus Zanthoxylum: A review. African Journal of Pure and Applied Chemistry, $5(12)$, 412-416. https://doi.org/10.5897/AJPAC.9000035

Panggabean, L., Nurhamidah, \& Handayani, D. (2020). Profil Fitokimia Dan Uji Sitotoksik Ekstrak Etanol Tumbuhan Zanthoxylum acanthopodium DC (Andaliman) Menggunakan Metode BLST. Jurnal Pendidikan Dan Ilmu Kimia, 4(1), 59-68. https://doi.org/10.33369/atp.v4i1.13711

Raja, R. N. L. \& Hartana, A. (2017). Variasi morfologi andaliman (Zanthoxylum acanthopodium) di Sumatra Utara. Floribunda, 5(7), 285-266. 
https://doi.org/10.32556/floribunda.v5i7.2 017.143

Sebayang, L. (2015). Tanaman andaliman (Zanthoxylum sp.) dan manfaatnya. Medan: Balai Pengkajian Teknologi Pertanian Sumatera Utara.

Siregar, B. L. (2012). Andaliman (Zanthoxylum acanthopodium $D C$ ) dan potensi pemanfaatannya. Media Unika, 84(2), 123-132.

https://123dok.com/document/yn42w71zperkecambahan-pematahan-andalimanzanthoxylum-acanthopodiumgermination-zanthoxylumacanthopodium.html

Silalahi, M., Lumbantobing, K., Studi, P., Biologi, P., Indonesia, U. K., Program, M., Pendidikan, S., \& Indonesia, U. K. (2021). Kandungan Minyak Atsiri Andaliman ( Zanthoxylum acanthopodium DC) dan Bioaktivitasnya. Jurnal Pro-Life, 8(1), 22-31.

https://www.researchgate.net/publication/ 350545592_Andaliman

Simbolon Isma, W., Kardhinata, E. H., Bangun, M. K., \& Simatupang, S. (2018). Identifikasi Karakter Morfologis Andaliman (Zanthoxylum acanthopodium DC.) di Beberapa Kabupaten di Sumatera Utara. 6(4), 745-756. https://www.bing.com/search?q=Simbol+ Identifikasi+Karakter+Morfologis+Andal iman+\%28Zanthoxylum+acanthopodium +DC.\%29+di+Beberapa+Kabupaten

Sinaga, R. E., \& Prasetyo, H. A. (2019). Upaya Memperpanjang Masa Simpan Andaliman ( Zanthoxylum acanthopodium D) Studi Kasus Desa Bandar Huta Usang Kabupaten Dairi Universitas Quality Email : $\quad$ roidasinaga20@gmail.com Abstrak. Agroteknosains, 3(02), 1-7. portaluniversitasquality.ac.id:5388/ojssyst em/... P PDF file

Sitanggang, F. M. C., Duniaji, A. S., \& Pratiwi, I. D. P. K. (2019). Daya Hambat Ekstrak Buah Andaliman (Zanthoxylum acanthopodium DC) Dalam Etil Asetat Terhadap Pertumbuhan Escherichia coli. Jurnal Ilmu Dan Teknologi Pangan (ITEPA), $\quad 8(3), \quad 257$. https://doi.org/10.24843/itepa.2019.v08.i0 3.p04

Silalahi, M., Lumbantobing, K., Studi, P., Biologi, P., Indonesia, U. K., Program, M., Pendidikan, S., \& Indonesia, U. K. (2021). Kandungan Minyak Atsiri Andaliman ( Zanthoxylum acanthopodium DC) dan Bioaktivitasnya. Jurnal Pro-Life, 8(1), 22-31.

https://www.researchgate.net/publication/ 350545592_Andaliman

Simbolon Isma, W., Kardhinata, E. H., Bangun, M. K., \& Simatupang, S. (2018). Identifikasi Karakter Morfologis Andaliman (Zanthoxylum acanthopodium DC.) di Beberapa Kabupaten di Sumatera Utara. 6(4), 745-756. https://www.bing.com/search?q=Simbol+ Identifikasi+Karakter+Morfologis+Andal iman+\%28Zanthoxylum+acanthopodium +DC.\%29+di+Beberapa+Kabupaten

Sinaga, R. E., \& Prasetyo, H. A. (2019). Upaya Memperpanjang Masa Simpan Andaliman ( Zanthoxylum acanthopodium D) Studi Kasus Desa Bandar Huta Usang Kabupaten Dairi Universitas Quality Email : roidasinaga20@gmail.com Abstrak. Agroteknosains, 3(02), 1-7. portaluniversitasquality.ac.id:5388/ojssyst em/... P PDF file

Sitanggang, F. M. C., Duniaji, A. S., \& Pratiwi, I. D. P. K. (2019). Daya Hambat Ekstrak Buah Andaliman (Zanthoxylum acanthopodium DC) Dalam Etil Asetat Terhadap Pertumbuhan Escherichia coli. Jurnal Ilmu Dan Teknologi Pangan (ITEPA), $\quad 8(3), \quad 257$. https://doi.org/10.24843/itepa.2019.v08.i0 3.p04

Susanti, N., \& Situmorang, E. (2020). Effectiveness of The Antibacterial Activity of n-Hexane Andaliman (Zanthoxylum Acanthopodium DC) 
Extract Against Bacillus subtilis, Salmonella typhi, and Staphylococcus AUREUS. Journal of Physics, 1-7.

Yanti, Pramudito T.E., Nuriasari N. and Juliana, K. (2011). Lemon pepper fruit extract (Zanthoxylum acanthopodium DC.) suppresses the expression of inflammatory mediators in lipopolysaccharide induced macrophages in vitro. American Journal of Biochemistry and Biotechnology, 7(4), 176-186.

https://www.bing.com/search?q=Lemon+ pepper+fruit+extract+\%28Zanthoxylum+ acanthopodium $+\mathrm{DC}$

Tarigan, I. L., Lumbantoruan, R., Sulistiara, E., Cintya, H., Candra, B. S., \& Sinaga, M. (2020). Pengaruh Ekstrak Andaliman (Zanthoxylum acanthopodium DC). Analit: Analytical and Environmental Chemistry, 5(2), 155-168. https://doi.org/10.23960/aec.v5.i2.2020.p $155-168$ 